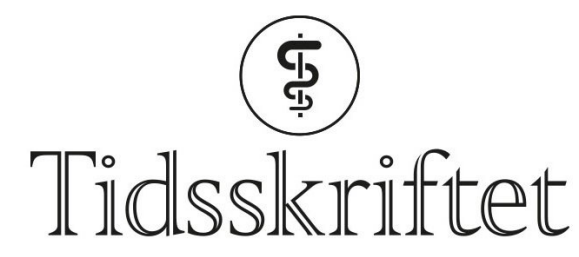

DEN NORSKE LEGEFORENING

\title{
Granulocytter kan fremme virusinfeksjon
}

FRA ANDRE TIDSSKRIFTER

HAAKON B. BENESTAD

Universitetet i Oslo

Nøytrofile granulocytter i slimhinnene forut for virussmitte kan øke virusreplikasjonen og forverre symptomene.

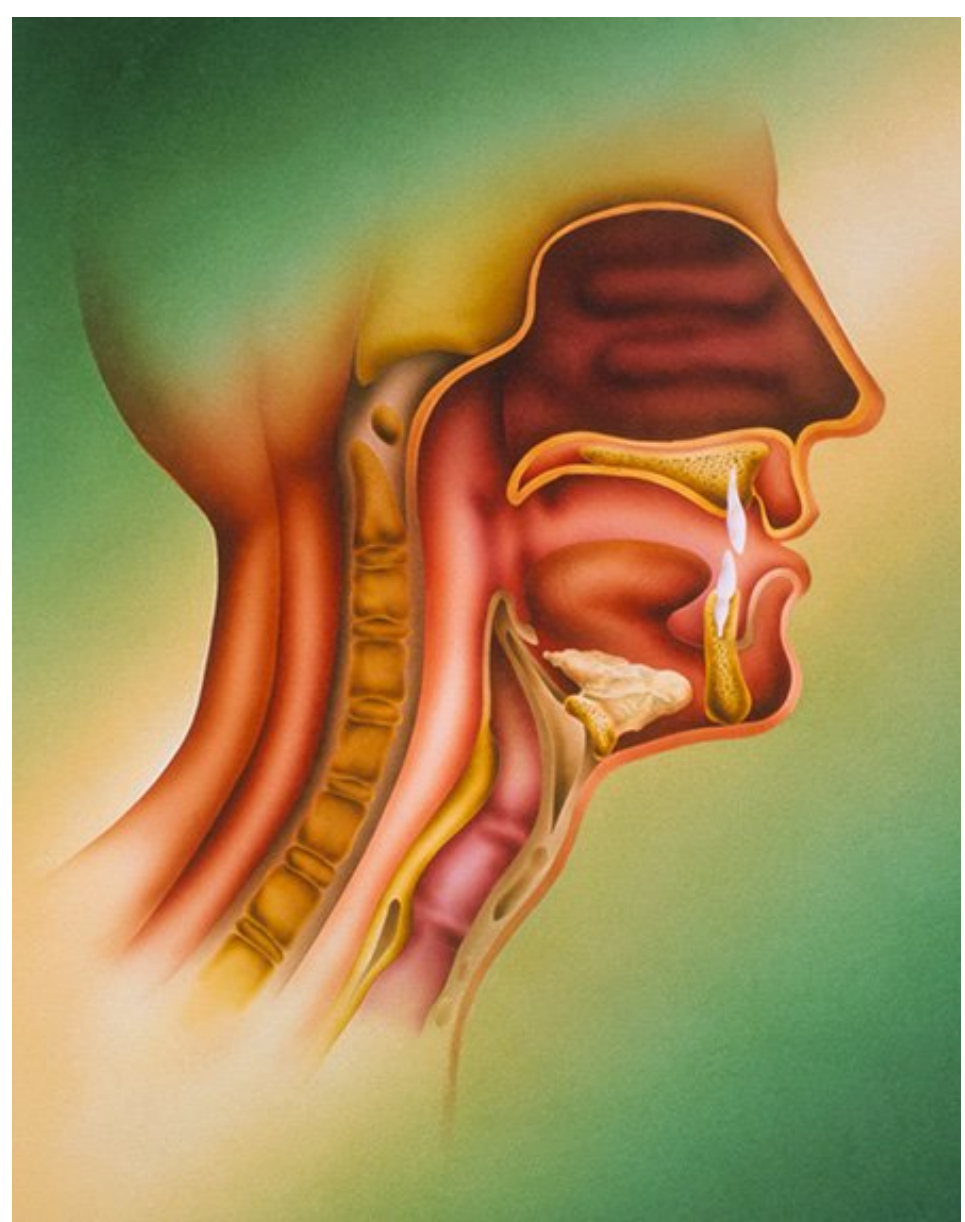

Illustrasjon: Science Photo Library/ NTB

Vi er vant til å tenke på nøytrofile granulocytter som førsteforsvaret mot akutte bakterieinfeksjoner. Men disse granulocyttene, som er ladet med celle- og mikrobedrepende skyts og dermed kan gjøre skade ved ikke-infeksiøse inflammasjoner, kan også være med på å danne et slimhinnemiljø som gjør verten mer mottakelig for 
virusinfeksjon.

Respiratorisk syncytialvirus (RS-virus) kan infisere småbarn og gi forkjølelsessykdom som i sjeldne tilfeller kan bli alvorlig og letal. Viruset kan også reinfisere til tross for at verten har utviklet spesifikk immunitet. I en ny studie var hypotesen at medfødt immunitet $\mathrm{i}$ respirasjonsveienes slimhinner, altså mikromiljøet på infeksjonsstedet, kan bestemme hvordan en RS-virusinfeksjon vil arte seg (1).

58 frivillige voksne ble inokulert med RS-virus gjennom nesen, men bare 33 av dem ble infisert. B- og T-celleimmunitet kunne ikke forklare hvem som ble infisert og hvem som ikke ble det. En transkriptomprofilering av nesevev og nesevask før infeksjonen, derimot, ga holdepunkter for en patofysiologisk forklaring: De som ble syke, viste tegn på at aktiverte nøytrofile granulocytter var til stede i slimhinnen før inokulering, men var uten symptomer på infeksjon. Infeksjonen var ledsaget av forsinket produksjon av pro-inflammatoriske cytokiner og kjemokiner sammenliknet med responsen hos de som ikke ble syke. Disse produserte markører for aktivert medfødt immunitet allerede i inkubasjonsfasen.

Resultatene ble delvis validert i en musemodell, der kjemokinindusert rekruttering av nøytrofile granulocytter til luftveiene like før RS-virusinokulasjonen økte den tidlige virusreplikasjonen og forverret symptomene, som ble drevet av CD8-positive T-celler. Forfatterne peker på likheter mellom infeksjon med RS-virus og SARS-CoV-2, da begge har lang inkubasjonstid.

- Denne studien viser hvor viktig det medfødte immunforsvaret er for å beskytte mot virusinfeksjoner, sier Frode Jahnsen, som er professor i patologi ved Universitetet i Oslo.

- Samtidig sier studien noe om hvordan immunforsvaret er regulert. Når man har nøytrofile granulocytter i slimhinnen, synes dette å hemme den akutte immunresponsen mot virus. Hvorfor det er nøytrofile granulocytter i slimhinnen hos presumptivt friske forsøkspersoner, er usikkert, men man kan tenke seg at luftveienes mikrobiota eller nylige subkliniske infeksjoner kan ha betydning, sier Jahnsen.

\section{LITTERATUR:}

1. Habibi MS, Thwaites RS, Chang M et al. Neutrophilic inflammation in the respiratory mucosa predisposes to RSV infection. Science 2020; 370: eaba9301. [PubMed][CrossRef]

Publisert: 14. desember 2020. Tidsskr Nor Legeforen. DOI: 10.4045/tidsskr.20.0880

(C) Tidsskrift for Den norske legeforening 2020. Lastet ned fra tidsskriftet.no 